\title{
11. NOTES ON INOCERAMUS, MESOZOIC BIVALVES FROM THE SOUTHEASTERN ATLANTIC, DSDP SITES 361 AND 364, LEG 40
}

\author{
Tatsuro Matsumoto, Department of Geology, Kyushu University, Fukuoka, Japan
}

\begin{abstract}
This paper describes, illustrates, and comments on fossil inocerami from the Upper Cretaceous of the Cape Basin Site 36I and the Lower Cretaceous Angola Basin Site 364 (Figure 1). The specimens from Site 361 are identified as fragments of a giant Inoceramus (?) sp. indet., those from Site 364 as Inoceramus sp. cf. Inoceramus anglicus Woods.
\end{abstract}

\section{PALEONTOLOGICAL DESCRIPTIONS}

Phylum MOLLUSCA

\section{Class BIVALVia}

\section{Order PTERIOIDA}

\section{Family INOCERAMIDAE}

Genus INOCERAMUS J. Sowerby, 1814

Remarks: Inoceramus in this paper is in a broad sense, including Mytiloides, etc.

\section{Inoceramus sp. cf. Inoceramus anglicus Woods}

(Plate 1, Figures 1a, b, 2a, b)

1911 Inoceramus anglicus Woods, Palaeontogr. Soc., 1910, p. 264. pl. 45 , fig. 8-10, text-fig. 29.

1961 Inoceramus anglicus Imlay, U.S. Geol. Surv. Prof. Paper, 335, p. 52 , p. 9, fig. $3,4,6$; pl. 10, fig. $1,4,9$.

1965 Inoceramus anglicus Pergament, Acad. Sci. USSR 118, p. 15 (with full synonymy list), including $I$. anglicus typica (p. $15, \mathrm{pl} .1$, fig. $1-3,4,6$; pl. 3 , fig. 2 ; pl. 5 , fig. 2 , 3; pl. 6, fig. 4 ; pl. 9 , fig. 6), I. anglicus conjugulis Pergament (p. 17, pl. 2, fig. 1, 2), and $I$. anglicus elongatus Pergament (p. 19, pl. 2, fig. 3, 4).

Locality: Two specimens, about $15 \mathrm{~mm}$ apart, from Sample 364 . $39-5,86-94 \mathrm{~cm}$. They are kept at the Type Collection of Kyushu University, under GK. H10108 (A, B) (lower specimen) and GK. H10109 (A, B) (upper specimen).

Description: GK. H10108 consists of the internal (A) and the external (B) mold of a right valve, whose prismatic layer is mostly attached to B but partly remains on A. They are all secondarily flattened, probably as a consequence of the load of the overlying sediments. Their anterodorsal part lies outside the core.

The two specimens lie parallel to the ill-defined lamination and are about $15 \mathrm{~mm}$ apart. Several shell layers, showing prismatic structures, are discernible in the intermediate part. GK. H10108 was prepared onboard ship, while GK. H10109 was worked on in the Paleontological Laboratory of Kyushu University by trimming along one of the laminae. It can be assumed that a fairly prolific Inoceramus-bearing bed was penetrated at this depth.

The two specimens are of similar size, outline, and ribbing. Although their anterodorsal part is deficient, the shell seems to have a subovate outline, showing a more evenly rounded ventral margin with growth. The posterior margin is gently curved, elongate, and forming an obtuse angle with the hinge line. The anterior margin is not clearly shown, but presumably moderately convex.

As the shell is secondarily compressed, the original convexity is not known. Presumably it was only gently inflated, as suggested by a slight inflation in GK. H10108. The posterior part must have been originally flattened

The dimensions cannot be accurately measured. The height is at least $60 \mathrm{~mm}$ and the length at least $50 \mathrm{~mm}$. The specimen presumably

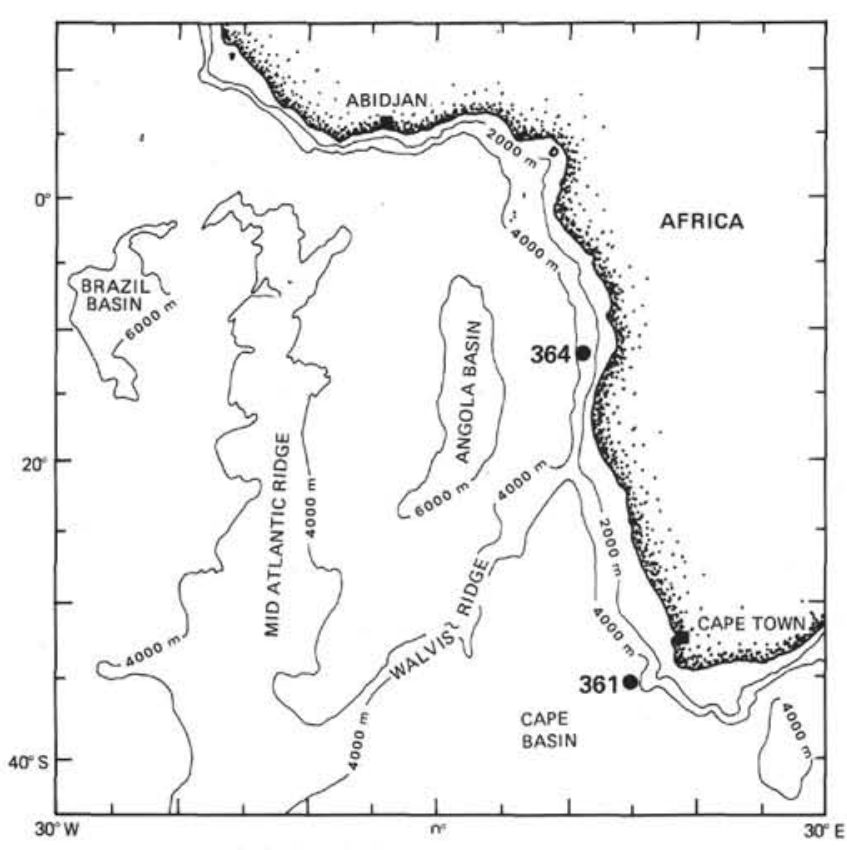

Figure 1. Location of DSDP Leg 40 Sites 361 and 364.

measures more than $70 \mathrm{~mm}$ along the axis of growth and about $60-65$ $\mathrm{mm}$ in "width" (measured perpendicular to the axis of growth). The axis of growth seems to run to the middle of the ventral margin, and is probably not very oblique.

The concentric ribbing is distinct and fairly regular in strength and distance. The ribs show a subsymmetrical curvature and are not as pronounced on the posterior flattened part of the shell. The ribs seem to have originally rounded summits, although the feature is somewhat modified in these secondarily compressed specimens. In GK. H10108 the ribs are separated by wider interspaces, but in GK. $\mathrm{H} 10109$ the ribs are somewhat more crowded and the interspaces are nearly as narrow as the ribs. Intercalation or bifurcation of the ribs sometimes occur in both specimens.

Discussion: Based on their characters, the two specimens are most probably Inoceramus anglicus Woods reported from the Albian of various areas. Because they are only incompletely preserved, the specimens are determined as Inoceramus sp. cf. Inoceramus anglicus.

Inoceramus anglicus Woods is a distinct, well recognized species, but it shows a certain extent of variation as demonstrated by the descriptions and illustrations of Woods (1912) and Imlay (1961). On material from Kamchatka, Pergament (1965) distinguished several forms within this species and proposed the subspecies typica, 
conjugulis, and elongatus. However, as they are nearly contemporary and lived in the same province, the present author considers such a splitting as unnecessary.

As far as conservable characters are concerned, GK. H10108 also closely resembles the specimen designated as the type of Inoceramus anglicus conjugulis Pergament (1965, p. 17, pl. 2, fig. 1), whose plastotype (GK. H9376) was presented to Kyushu University by V.V. Menner. In rib density GK. H10108 is not much different from a typical example of Woods (1912, text-fig. 29, Sedgwick Museum B42047), from the Albian Red Limestone of England, but its ribs show a more broadly rounded curvature than the British specimen.

The ribs in GK. H10109 are nearly as close as in another specimen from the same Red Limestone figured by Woods (1912, pl. 45, fig. 8).

Another species which should be brought into comparison is Inoceramus comancheanus Cragin, $1893^{\prime}$ (see Adkins, 1928, p. 92 , pl. 18, fig. 5; Reeside, 1923 , p. 202 , pl. 14, fig. 1-7), from the Albian of the Western Interior province and the Gulf Coast province of the United States. In our opinion this species belongs to the same group as Inoceramus anglicus, but its shell is narrower, having a smaller beak angle, and is distinctly more elongate along the growth axis which runs more obliquely than in Inoceramus anglicus. The ribbing of Inoceramus comancheanus is rather irregular. It is interesting to note that Inoceramus cf. comancheamus was reported from the Albian of Kamchatka (Pergament, 1965, p. 27, pl. 9, fig. I, 2 ) and Inoceramus aff. comancheanus from the basal Cenomanian of the French Alps (Eigenheer and Sornay, 1974, p. 1, pl. 1). They possess essentially the same characters as the typical Inoceramus comancheanus. Therefore, the specimens described here are not identified with any of the above-mentioned Inoceramus comancheanus and allied forms.

Gnesioceramus comancheanus of Heinz (1933, p. 247, pl. 16, fig. 1,2), from Madagascar, is also different because of stronger ribbing and greater inflation of the valve.

Matrix: The matrix is an olive-gray marly limestone. Under the microscope the sediment contains several percent microfossils, including globigerinid foraminifers (probably belonging to Globigerinelloides) and at least two species of radiolarians (probably belonging to the suborder Spumellina) shells replaced by calcite. The main portion of the matrix consists of (a) micritic calcite (4-10 $\mu \mathrm{m}$; in part patchily recrystallized up to $2 \mu \mathrm{m}$ ), which may possibly contain coccolithophorids, (b) fossils internally filled with coarse mosaic calcite of mostly $20-40 \mu \mathrm{m}$, (c) a smaller amount of quartz of probably diagenetic origin (not of detrital origin), and (d) fairly common iron mineral (probably pyrite), disseminated in the matrix and also inside the microfossils, which show irregular shapeslumpal, dendroid, amoebic, etc. In addition to the above constituents, other indeterminable compounds occur in patches or irregularly and are impregnated by brownish material, which appears to be of organic origin. No detrital grains are discernible in the thin section and the rock should be called a foraminifer-Radiolaria micrite. (Dr. Kametoshi Kanmera supplied the above petrographical observations and Dr. Tomowo Ozawa the identification of foraminifers).

Geographic Distribution, Ecology: Inoceramus anglicus Woods is widespread in the Albian, as indicated in a world map by Pergament (1965, fig. 1). The known localities are mostly in the Northern Hemisphere, but Pergament also shows occurrences in Madagascar and New Zealand. Little is known on the mode of life of this species, but as in many species of thin-shelled Inoceramus, it may have been pseudoplanktonic, at least in its juvenile stage (Hayami, 1969). In that sense Inoceramus anglicus was "semipelagic" as was Inoceramus labiatus in the lower Turonian. In fact Inoceramus labiatus can be considered to have belonged to the same stock as Inoceramus anglicus and Inoceramus comancheamus. Certain species belonging to the same phylogenetic series, e.g., Inoceramus teraokai Matsumoto and Noda (1968) and Inoceramus mantelli Mercy (see Seitz, 1962), have anterior ears which suggest the attachment to a floating substance even in the adult stage. The occurrence of Inoceramus anglicus and the nature of the sediment in which it occurred indicate a freely circulating open sea, rather than a poorly circulating, restricted sea for the Albian of the southeastern part of the Atlantic here under consideration. The occurrence of several shells of the same species within $15 \mathrm{~mm}$ of

${ }^{1}$ Plaster casts of syntypes of Inoceramus comancheanus Cragın are in Kyushu University, GK. H9194 and GK. H9195. sediment indicates a rapid rate of sedimentation despite the apparent pelagic character.

\section{Inoceramus (?) sp. indet. \\ (Plate 1, Figures 3a, b)}

Locality: Several fragmentary shell layers embedded nearly parallel to one another in a calcareous claystone sample of about 40 mm thicknesss from DSDP Leg 40, Sample 361-15, CC. The sample is registered at Type Room, Kyushu University, GK. H10110.

Description: The largest shell layer fragment is $65 \mathrm{~mm}$ in maximum length and $5.1 \mathrm{~mm}$ in maximum thickness. Megascopically the shell layers show a prismatic structure which is quite similar to that of Inoceramus. Assuming that they are fragments of large Inoceramus shells, the species must be of a giant size or some of the fragments may be a part of the hinge plate where a shell layer is thickened.

Examples of large Inoceramus (over $300 \mathrm{~mm}$ in height) are known from various Upper Cretaceous stages. For instance Inoceramus hobetsensis Nagao and Matsumoto from the middle part of the Turonian in Hokkaido, Sakhalin, and Kyushu, Inoceramus amakusensis Nagao and Matsumoto from the Santonian of Kyushu and Hokkaido, and Inoceramus schmidti Michael from the Campanian of Sakhalin and Hokkaido. Inoceramus expansus Baily (1855) from the Santonian of South Africa may be another example of giants as is Inoceramus grandis (Conrad) in the lower Senonian of Kansas. As these fossil species were established mostly on the internal or external mold, reliable information is rather rare for the actual thickness of the shell layer, but in many cases the shell is comparatively thin for its large size, as mentioned by Hayami (1969).

As Tanabe (1974) has shown, Inoceramus schmidti has a somewhat thicker shell in later growth stages, acquiring a benthic mode of life. The large shells occur in some but not in all populations.

Although the above suggests that giant species of Inoceramus are rather common in the Senonian (Coniacian to Campanian) in various regions of the world, it is not possible to identify the fragments at hand. It cannot even be determined with certainty whether they belong to the genus Inoceramus. They are here therefore labeled as Inoceramus (?) sp. indet.

\section{ACKNOWLEDGMENTS}

Thanks are extended to Dr. Hans M. Bolli and Dr. Hideo Kagami who supplied these valuable specimens for study along with necessary information, to Drs. Kametoshi Kanmera, Tomowo Ozawa, Hiromichi Hirano, Hitoshi Momoi, and Fumitoshi Hirowatari, for their help in the laboratory at Kyushu University, and to Miss Mutsuko Hayashida for her assistance in preparing the typescript.

\section{REFERENCES}

Adkins, W.S., 1928. Handbook of Texas Cretaceous fossils: Univ. Texas Bull., v. 2838, p. 1-303.

Bailey, W.H., 1855. Description of some Cretaceous fossils from South Africa: Quart. J. Geol. Soc. London, v. 11, p. 454-465, pls. 11-13.

Cragin, F.W., 1893. A contribution to the invertebrate paleontology of the Texas Cretaceous: Geol. Surv. Texas. 4th Ann. Rept. (1892):v. 2, p. 141-246.

Eigenheer, R. and Sornay, J., 1974. Sur une forme apparentée à Inoceramus comancheanus Cragin dans le Cénomanien basal de Montlaux (Alpes-de-Provence): Bull. Mus. Nat. d'Hist. Nat., v. 3, p. 141-144.

Hayami, I., 1969. Notes on Mesozoic "planktonic" bivalves: J. Geol. Soc. Japan, v. 75 , p. 375-385 (in Japanese with English abstract).

Heinz, R., 1933. Inoceramen von Madagascar und ihre Bedeutung für die Kreide-stratigraphie: Z. Deut. Geol. Gesell., v. 85 , p. 241-259.

Imlay, R.W., 1961. Characteristic Lower Cretaceous megafossils from northern Alaska: U.S. Geol. Surv. Prof. Paper 335 , p. $1-73$. 
Matsumoto, T. and Noda, M., 1965. An interesting species of Inoceramus from the Upper Cretaceous of Kyushu: Trans. Proc. Palaeontol. Soc. Japan, Trans., v. 71, p. 317-325.

Nagao, T. and Matsumoto, T., 1939-1940. A monograph of the Cretaceous Inoceramus of Japan: Jour. Fac. Sci., Hokkaido Imp. Univ. [4], 4, p. 241-299, pls. 23-24 [1-12] 1939; Ibid., 6, p. 1-64, pls. 1-22 [13-14].

Pergament, M.A., 1965. Inoceramus and Cretaceous stratigraphy of the Pacific region: Acad. Sci. USSR. Geol. Inst., Trans., 118, p. 1-99.

Reeside, J.B., Jr., 1923. The fauna of the so-called Dakota formation of northern central Colorado and its equivalent in the southeastern Wyoming: U.S. Geol. Surv. Prof. Paper 131 H, p. 199-207.

Seitz, O., 1962. Úber Inoceramus (Platyceramus) mantelli Mercy (Barrois) as dem Coniac und die Frage des ByssusAusschnittes bei Oberkreide-Inoceramen: Geol. Jahrb., v. 79, p. $353-386$.

Tanabe, K., 1973. Evolution and mode of life of Inoceramus (Sphenoceramus) naumanni Yokoyama emend., an Upper Cretaceous bivalve: Proc. Paleontol. Soc. Japan, Trans., v. 92, p. $163-184$

Woods, H., 1911. A monograph of the Cretaceous Lamellibranchia of England, 2, pt. 7: Palaeontogr. Soc., 1910. p. 261-284. 


\section{PLATE 1}

Figures I, 2 Inoceramus sp. cf. Inoceramus anglicus Woods.

1. Left valve (GK. H10108); (a) internal mold (GK. H10108 A); (b) external mold, with partly preserved shell layer (GK. H10108 B).

2. Right valve (GK. H10109); (a) internal mold (GK. H10109 A); (b) inner surface of a shell layer and in part external mold (GK. H10109 B). Sample 364-39-5, 86-94 cm.

Figure $3 \quad$ Inoceramus (?) sp. indet.

Core with several layers of shell fragments. (a) lateral view, (b) oblique view from other side. Sample 361-15, CC. 
PLATE 1
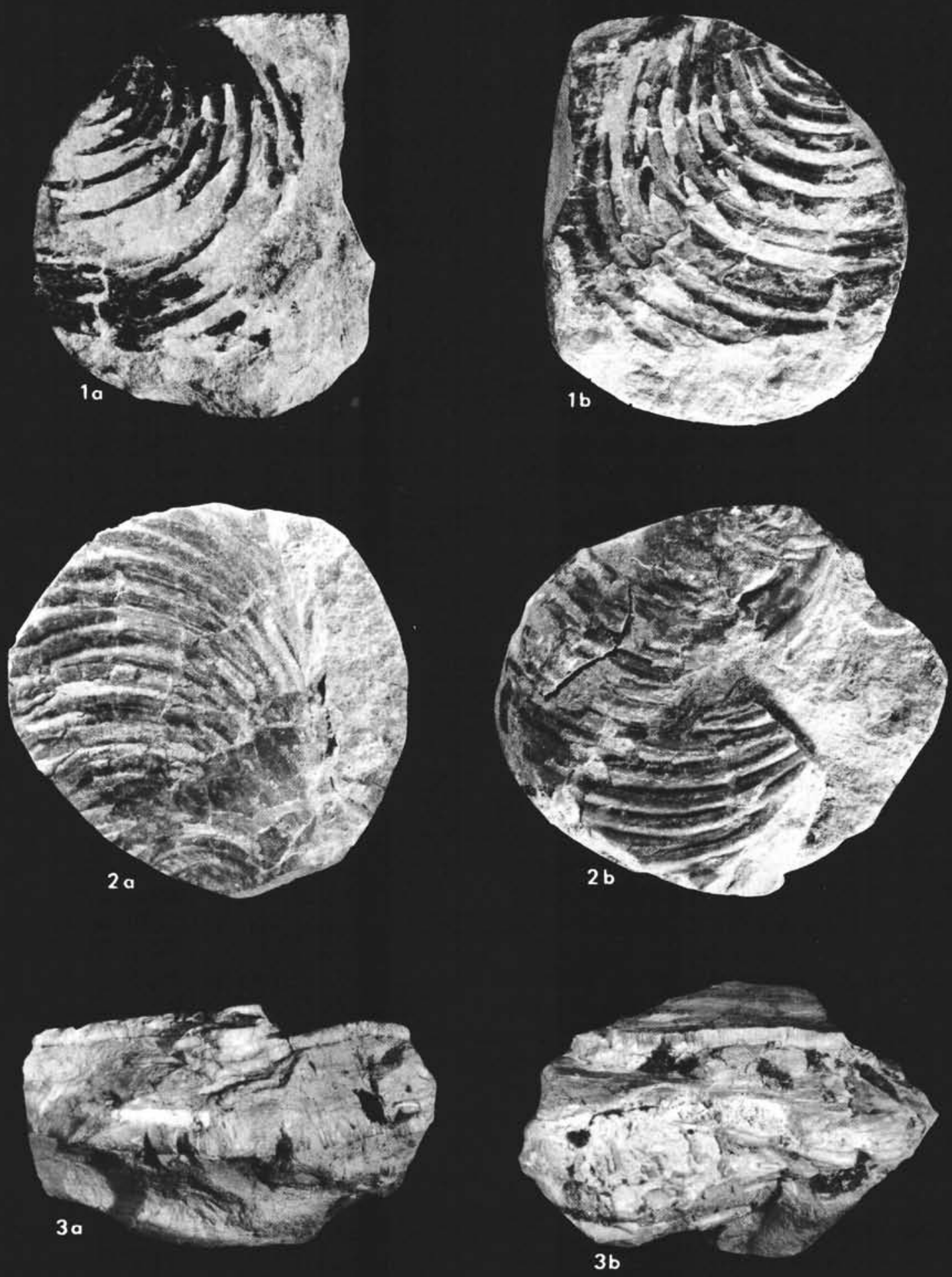